Himalayan Journal of Sociology \& Anthropology-Vol. III

\title{
Quandary in Nepal: A Conflict Perspective
}

\section{Prakash Upadhyay, Ph.D.}

\begin{abstract}
This article, under the theoretical parasol of conflict perspective, converses on veracities of current Nepal, rising conflicts, paradigm shifts and deepening crisis amidst the proposed constituent assembly elections. It is astringent veracity that after the successful movement of 2006 and the country being on the threshold of constituent assembly elections, in the present, the major segments of precautious civil society and commoners are questioning the validity of politics, operation pattern of political parties, and the distribution of rights and scarce resources among the elites rather than among masses. I argue that the more, practices of dominant ruling elite segments and their fraternal organizations are creating alienative disposition from the grievances of commoners, the more is the deepening crisis and more civil society, common public becoming aware of their true collective interest by communicating their grievances to each other and questioning the validity of activities of dominant ruling elites. Yet the ruling elites, their actions, words and promises remains more a rhetoric and moribund in Nepal and may prove a nightmare if ongoing conflicts are left unresolved.
\end{abstract}

[Key words : Quandary, Conflict, Republic]

Prelude: Moderately a petite country of Asia, Nepal with its preserved glory of being independent and sovereign throughout history, has recently witnessed people's historic movement, a kind of revolution against the monarchy. The aftermath of revolution is also not free of troubles which are evident from recent uprising in terai, Chure-Bhavar region, and demand of ethnic minorities for representation with identity in all spheres of the nation. Delimited by the giant communist China to the north and democratic India to the east, west and south, Nepal's political identity and status has been to great extent influenced by Indian and American foreign policy interest which is resulting in the form of latent or manifest form of interference in the internal affairs of Nepal-political, economic, socialcultural. Being mainly an agricultural country with major section of population dependent on agriculture, semi feudalistic social structure exists even in the twenty first century in Nepal which has prepared the ground 


\section{Quandary .... (Upadhyay)}

for all sorts of dependency - external as well internal. The long established totalitarian governments and feudalistic nature of governance also helped in the maintenance of semi-feudalism even to these days. Until 1951, members of the autocratic feudalistic Rana family held complete control of the government in Nepal with a familial oligarchy. In 1950 after a revolt led by the Political parties, Rana rule came to an end but the residual of feudalism with political nexus and dependency enduring still to the present being responsible for all sorts of quandaries thus preparing the ground for the perusal of the prevailing current problems from the conflict perspective.

Conflict perspective holds the notion that humans are unique owing to caliber of their conscious awareness of themselves and their situation. They are capable of self - reflection and hence, assessment of their positions in society is possible through their self-consciousness (Marx, 1859). Such consciousness arises out of people's daily existence and is not a realm of ideas that is somehow independent of the material world of elites. In Nepal also self-consciousness of masses and humanly may be the history, a change from feudalistic age to multiparty democracy after the people's movements in different time phases. High elite culture and elitism as coined by Gaetanae Mosca a century back, still dominates urban as we ${ }^{1} l l$ as rural Nepal which is a reminisce of feudalism partly in semi feudalistic form operated by elites. Nepal, a small country of Asia with a Shangri-La image, is bounded by lofty hills and unique culture with its preserved glory of being a self-sufficient and self-governing country throughout human history amidst prevailing elitism.

The term elite itself is confusing and elastic with various meanings, depending upon the type of establishment, society, agro-based economy, culture and change. The world around us is a materialization of man's praxis; his prolific activity in history is not just an assertion that nature is man made. Man's understanding of the material world is a reflection of his own social world. Marx claimed that the history of all hitherto existing society is the history of class struggle. He says "free man and slave, patrician and plebian, lord and serf, guild master and Journey man in a word, 
Himalayan Journal of Sociology \& Anthropology-Vol. III

oppressor and oppressed, stood in constant apposition to one another, carried on an uninterrupted, now hidden, now open fight that each time ended either in a revolutionary reconstruction of society at large with the annihilation of elitism or in the common ruin of contending classes. In Nepal too, the long history of totalitarian governments and feudalistic nature of governance augmented the upholding process of semi-feudalism. Throughout its history, there has been the existence of ruling elites, political elites or elites of different kinds of social and economic strata in the Nepalese society. Although, 'Republic', a much discussed notion in the present, Nepal has been basically governed by the " ruling elites” throughout history. Before the Rana regime (1768-1846 AD), few elite families such as the Thapa, Basnyat and Pandey ruled Nepal under the banner of Shah Kings. During Rana regime (1846-1950 AD), members of the autocratic feudalistic familial oligarchy of Rana family held complete control of the government in Nepal. After the end of Rana rule in 1951 first free elections were held in 1959 and a new constitution introduced, however, in Dec. 1960 King Mahendra banned all political parties and suspended the constitution. In 1962, a new constitution was drafted which set up a partyless Panchayati government and non-party council known as the Rashtriya Panchayat with king as the autocratic executive head of the elite government. Few elite families who were very close to Narayanhiti Palace ruled Nepal, took advantage and emerged as neo-elites and in long run became political elites leading to increasing polarization between commoners and elites. Because of high concentration of elites in Kathmandu, there resulted in regional bias in development with the high development of Kathmandu and other city areas and the underdevelopment of secluded regions, hence cultural, social, economic, political, ethnic and all divergences with their historical legacy consequently becoming a hearth for all crisis in the present. The political ambitions in nexus with grievances of people were visible during the 19 day glorious movement of the people against the autocratic luxurious monarchy-the nostalgia of elites. However the aftermath of movement witnessed people's strong sentiments and demand for more inclusiveness, more regional autonomy, social, political, economic, ethnic and other changes. Amidst a vicious cycle of crisis, the current crisis in Nepal is explainable 
on the base of a set of hypotheses about social/cultural, ethnic, regional, economic, political relations especially about a demand for more autonomy, social/cultural, ethnic, regional, economic, political rights and inclusiveness and more rapid changes.

Appraisal of Crisis in Nepal; a Conflict Outlook: Conflict perspective is embedded with Marxist Anthropology which developed in response to discontent with numerous facets of contemporary anthropological theory. Most notably, perhaps, Marxist anthropology questioned the validity of treating small-scale societies as isolated, suspended in time and space, rather than as elements in colonial and postcolonial world. Marxist anthropology also presented itself in a quite different way as it questioned both "functionalists tendency" to attribute equal force to all elements in the social system, and the 'Structuralists' claims that social life was driven by the structure of people's thought rather than the practical outcome of their actions. Robert Layton (1993) argued that Structural Marxists sought a compromise position, arguing that the material conditions of existence cannot completely determine people's ideas. Harris also followed Marx's dictum that people's ideas (consciousness) are determined by their embeddedness in a mode of production, but adhered to the enlightenment principle that the detached observer is exempt and can objectively determine the true causes of events. But Harris rejects the converse proposition, that people's ideas can have a determinative effect on their material or social condition.

More than one and half century back, Marx had argued that the quintessence of people's lives is the process of production since for Marx, human life involves before anything else eating and drinking, a habitation, clothing, and many other material things. To meet these necessities of life, production is necessary, but as production satisfies one set of needs, new needs arise and encourage alterations in the ways that productive activity is organized. The elaboration of productive activity creates a division of labor, which, in the end, is alienating because it increasingly deprives human of their capacity to determine their productive activities and supports the elites. The track of history right from the development of societies to present 
involved processes as people vigorously restructure the material conditions of their existence and in the process crisis occurs in the course of demand for more social, economic, political, ethnic and other rights on the part of commoners.

While describing the historical development of human society Marx used the concept of "Primitive communism". He believed that the early stage of human society was the stage of primitive communism followed by other stages. Anthropologists in their own way reassessed Marx’s stages leading to modern human society with the reinterpretations of philosophies of society and culture. There have been several areas where Marx's work has been analyzed from anthropological point of view. In the analysis of class structure, several early Marxist argued that Marx's scheme had to be revised because there was no real sign of heightened class struggle. A good deal of effort has been expanded in an attempt to adapt the basic idea of a necessary conflict between labor and capital to the conditions of contemporary societies. All these efforts have taken the form of new theories of social class to take account of changes in the patterns of property ownerships changes in relationships at work, class divisions, rise of elitism and side by side growth of more conscious middle class also, exploitation, growing unrests and the reasons behind conflicts also remaining vital. It is also been widespread realized that it is virtually impossible to comprehend and solve the problems related to social unrests in the absence of a proper mechanism explaining the relationship between the growing elitism with its historical legacy and the scramble for more autonomy, social/cultural, economic and political rights on the part of citizens.

Establishing the correlation between current Nepalese crisis and the conflict perspective, it is evident that Nepalese economy has taken the form of distinguishing different capital fractions and of providing an account of the monopoly phase of elites. How differences of power develop when elitism is institutionalized, sharing of productive resources to commoners is the issue of special enquiry in the present. Scholar like George Simmel had also claimed half a century back that society is chock-a-block of conflicts and harmony, hatred, love, repulsion, attraction owing to growing economic 
gulf between masses and elites. Coser (1964) even argued that conflicts have some social functions and implications, which ought to be seen at the levels of conflicting parts and at the system as a whole. But the growing unrest in different parts of Nepal and incidents aftermath makes it clear that although conflicts may have functions in bringing different changes, however when more unequal is the distribution of scarce resources; the greater is the conflict of interest between dominant and subordinate segments in a system. The more subordinate segments become aware of their true collective interests, the more likely are they to question the legitimacy of the existing pattern of distribution of scarce resources in the hands of elites. The more social changes brought by dominant segments disrupt the existing relations among subordinates; the more likely are the masses to become aware of their true interest. The more the practices of dominant segments create alienative dispositions among subordinates; the more likely are the latter to become aware of their true collective interest. The more members of subordinate segments can pass on their grievances to each other, the more probable they are to become conscious of their true shared interests. The further subordinate segments of a system are aware of their collective interests and the greater is their questioning of the validity of the distribution of political power, political actions and scarce resources, the more likely are they to join overt conflict against dominant elite segments of a system. Likewise, when greater is the ideological amalgamation of members of subordinate segments of a system, the additional the chances of polarization of subjugated segments of the society. If the overriding is more polarized, the more rigorous is the conflict in the form of more rights. If the divergence is more violent, greater structural alteration will occur and the scarce resources available will be distributed in a fair way to all despite divergences of the people living in terai, hills and mountain in the perspective of Nepal.

Amidst discrepancies, in modern Nepal the student's movement and the consequent referendum of 1980 provided people a choice between a reformed version of the existing partyless Panchayati system or a multiparty based system, which resulted in the return of the existing party less Panchayati system amidst election manipulation and mass misuse of state 
machinery by elite government. In June 1985 an underground extremist group launched a bombing campaign against monarchy in which many people were killed. The state arrested thousands of opposition supporters. In 1989, Nepal's relation with India became tense when the Indian government under Rajiv Gandhi imposed an economic blockage over a dispute regarding their 1950 "Special Relationship Treaty". The fall of Berlin wall and east European Communism, visit of Indian political leaders Chandrasekhar, Harkishan Singh Surjeet in February 1990 to express Indian solidarity to Nepalese political parties prepared the ground for the coalition of political parties (who were never united in the past) and demand for the restoration of multi party democracy in Nepal. The successful movement in 1990 led to the end of king's direct rule and the formation of an interim all party government.

Democratic period in Nepal also remained embedded in divergences. Since 1990 to 2007, Nepal saw various forms of government (single, coalition), political malfunctions, resulting in political instability that jeopardized the whole country consequently resulting in the raise of Maoist uprising badly affecting the newly established democracy and all and everything in Nepal. Dahal (2000) had argued that even in modern democratic age also, poor people in Nepal are not the real beneficiaries in development projects and the elites living on the top have always remained the true beneficiaries of all development models. He further argued that Nepali culture in essence, is strictly built hierarchical and inherently built -in with the values of ambiguities and contradictions in everyday speech and work and because of these perpetuating cultural values, the Nepalese democracy has not been able to cross the barriers of caste, family and kinship and therefore leading towards 'inaction' and unrests in every aspect of the society. He stressed that all foreigners as well policy makers should understand that Nepali society is pluralistic society and a homogenous model of development may or may not work. In fact it is a bitter authenticity that even after all political exercises, the governance system remained the reflection of the past legacy; the old traditional elites still occupy key positions in every institution all over the country. The same domineering elitist structure based on family and kinship nepotism operates and the bottom-up process of 
democratic politics remained a distant dream in Nepal. Democracy remained part time -democracy only for few elites. The grass root democracy stands only rhetoric.

There led to ascend of new political power paradigm in the political horizon of Nepal after 2001, it was a paradigm shift in apathy to political parties who at that time were involved in different sort of malfunctioning. It weakened the democratic forces and institutions in Nepal and to great extent political parties were responsible for the weakening position of democratic institutions. The new king Gyanendra grabbing the opportunity of weakening political parties dismissed the government of prime minister Sher Bahadur Deuba for the second time and took over executive power in his hand in January 2005 and declared emergency. During the mid of Dashain in October 2005, the autocratic monarch's government brought much criticized Media Ordinance in the words of Information ministry to regulate the media sector of Nepal. However the civil society and parties severely criticized the ordinance and appealed the international community to oppose the ordinance. The office of the UN High commissioner for human Rights (OHCHR) in Nepal claimed that the new media ordinance "violated international human rights standards" and it lacked respect for the rule of law in Nepal. The seizure of broadcasting equipments from radio stations and a large deployment of armed police raised serious issues regarding respect for the rule of law as well as respect for freedom of expression in Nepal. OHCHR said that it regard media ordinance restrictions too broad, ambiguously worded, and sufficiently focused on a specific threat. US Senator Tom Daschle who visited Nepal in July 2005 criticized the ordinance and termed as dangerous the steps taken by government to muzzle independent media.

Amidst all suffocations under the elitist rule of autocratic monarch, deadlocks, development stalemate, and exploitations paved the way for people's historic heroic movement recently witnessed in Nepal which is a kind of revolution against all sorts of elitism-specially the monarchy's elitism and autocracy. The Narayanhiti palace massacre, ostracized activities of king and crown prince, brought Nepal on the threshold of corrosion with a 
new political polarization and a political paradigm shift against the king and in favour of political parties. Seven parliamentarian political parties signed 12 point understandings with the then banned Maoist militia in late 2005 and this led to a paradigm shift from constitutional monarchy to Loktantric (democratic) People's Republic. Ignoring the political paradigm shift and mass sentiments, kings autocratic government announced the local elections for the municipalities on February 8, 2006 and general elections conducted with a total cast vote of meager $19 \%$. India and other democratic powers including USA and European Union refuted to give validity to the so called drama election. The Maoist insurgents by the time were engaged in waging war against state from jungle and many rural districts of western Nepal was under their hold.

Political parties declared so called elections as meaningless and actively boycotted the polls. Parties also provided the top alliance leaders the mandate to continue further talks with the insurgents Maoist which paved the ground for another political paradigm shift- a new paradigm shift integrating seven parliamentary parties with Maoist. This paradigm shift was owing to autocratic and dictatorial rule of the king and with dissatisfaction with several aspects of contemporary political events. Most importantly, political parties, common people and civil society questioned the validity of treating political parties as isolated from the people by the autocratic king Gyanendra and his eccentric son crown prince Paras by adopting the policy of divide and rule. Kings act was suspended in time and space, rather than as elements working for the welfare of the people. Haunted by palace ghost Nepalese people ultimately challenged the dictatorial rule of king in April 2006 on the call of seven political parties and the then underground Maoist. A nineteen days people's heroic movement and the martyrdom of more than two dozens lives, mutilation of thousands compelled the autocratic monarch to surrender before the people and to hand over power to political parties. In historical perspective, in fact, people's frustration had developed in response to dissatisfaction with several aspects of contemporary political events consequently paving the way for the people's movement part—2 in April 2006 consequently leading to the downfall of monarchy consequently preparing the ground for Loktantrik 
Ganatantra. Most significantly, common people and civil society questioned the validity of monarchy as isolated from the people, suspended in time and space, rather than as elements working for the welfare of the people. Common Nepali is also questioning the tendency to attribute equal force to all elements (parties, palace, and military) in the political system. Public is thinking that monarchy is only for the fulfillment of its own vested interest rather than thinking about people's grievances and the practical outcome of their actions, thus the only solution is the 'Republican system of government' . In this regard a position endorsed is to accept people's supremacy and their verdict in the form of republican elections in future. It should be taken for granted that ruler's ideas and policies can have a determinative effect on common people's material, political or social condition, at the same time people's verdict, views and attitude can also have a decisive effect on ruler's status. In fact, no sustainable stability, peace and total inclusive Loktantra will be achieved in Nepal until this interdependent relationship is considered.

\section{Conclusion}

In July 2007, the cabinet discarded the old National Anthem praising king may king long live (composed by Chakrapani Chalise a century back) and introduced a new Anthem written by a common Nepali Byakul Maila; this anthem praised the glorious history of Nepal and Nepalese. In August 2007, the committee for the confiscation and nationalization of Kings Property, under the chairmanship of Home minister Krishna Prasad Sitaula, confiscated thousands of hectors of king's landholdings and forest areas. This committee also nationalized the Narayanhiti palace (where presently the king used to reside and who left the palace on August 8, 2007 for a short period of time after the nationalization of the palace) and more than one dozen palaces owned by king Gyanendra. It has been commonly believed that lopsided distribution of resources in favour of elite king, concentration of scarce resources in elite hands, political power and century's old feudalistic exploitations lead to the augmentation of poor Nepalese's frustration that created further crisis and instability that led to the downfall of Monarchy. But similar to French revolution of 1789 AD, in the lack of proper governance and control mechanism on the part of seven 
Himalayan Journal of Sociology \& Anthropology-Vol. III

political parties government and their reluctance and lack of vision to dispatch autonomy and more power to commoners, various sorts of unrests, strikes, violence and even crimes emerged and when politicized got a political colour in the form of political violence in terai and other regions in the hills and cities of Nepal.

No one can ignore that social/political divergence or conflict is the core of change as a general process and essential law of development occurring amidst scarcity. In aftermath of glorious movement of 2006, unequal distribution of resources, political power and centuries old feudalistic elites exploitations amidst the rhetoric of Samabesi (inclusiveness) lead to the rise of crisis and instability, ultimately leading to conflict and violence and when politicized got a political colour even in the form of political violence in the aftermath of peoples movement. Thus, peoples strong protest of elitism, raising awareness, demand for more rights ,inclusiveness, autonomy are genuine issues and should be addressed in time. Likewise, the more imbalanced the regional development efforts and allotment of limited wherewithal and political power in Nepal; the wider will be the inconsistency of interest between foremost and secondary segments for receiving the power on possessions and political power. At the same time more the public view is ignored, more violent the society will be. The further common Nepali residing in mountain, hill and terai become aware of their factual combined interests; the more likely are they to challenge the legitimacy of the existing pattern of politics and the distribution of a major bulk of scarce resources in the hands of few elites. No one in present day Nepal should take the fate of the common people of Nepal (both urban and rural mass) as scapegoat to slaughter. Rather the ruling segment should think about populace by seeking people's consensus and sentiments either at the time of issuing media ordinance or at the time of announcing polls or at the time of taking any kind of action detrimental to peoples interest. If the sentiment of the majority of people is ignored there may be more apathy, violence and non-participation of the people in all activities of the Loktantrik process. Peace process under UNMIN (United Nation mission in Nepal), monitoring and listing of Maoist army and their weapons may come under the threat of rising conflict which may derail the route to constituent assembly 
(Although by the time of writing of this article the seven political parties had signed 23 points agreement and Maoist had also agreed to join the government which has brightened the prospects of constituent assembly elections).

Other tribulations are also not as easy as because of terai unrest, strike for more rights by ethnic minorities (although government has signed agreement with ethnic groups and indigenous nationalities). The ignorance of public's regional sentiment may create more unrest in future the philosophy of Political Sociology argues. The coalition of eight parties (now converted to seven after the unification of Nepali Congress) had become the synonym of $3+5$ which was identical to the myth of $3+5$ coalition of Rana rule of 104 years (1846-1950) and 238 years rule of Shah Rulers (1768-2006). The Rana ruler had adopted the honorary title of Shree 3 and the Shah Kings were honored by the title of Shree 5 -both a feudalistic elite title. The political parties and their collation government are in many cases ignoring the civil society and other grass root level organizations which are very much close to people and which also played a vital role in making successful the 19 days movements viz FECOFUN (Federation of Community Forestry Users in Nepal, one of the largest organizations in Asia) .The collation government is embedded in a whirlwind of rising ambitions, nepotism, strikes, politicization of educational institutions. Mishra (2007) has argued that history, process, transition etc sought to be intrinsically implicated in all formulations and a present without a past and a future-an ahistorical present -has always left him queasy. Hence, the government while in the process to get a solution to all strifes ought to ponder on the historical legacy (past) of elitism, inequalities and the perpetuating social-cultural-regional and economic values. The major segments of civil society in Nepal is also becoming aware of peoples collective interests and are questioning the authority of prevailing pattern of politics, functioning of political parties. They are also demanding for the equal distribution of scarce resources and social, political rights and opportunities among the citizens which may bring an end to crisis in future. It is also convinced that the more the activities of dominant ruling political elites and their fraternal organization try to impose supremacy and make 
common people and civil society more frustrated by their undemocratic activities, the more likely are the civil society, common public to become sentient of their genuine collective interest by corresponding their grievances to each other. The ruling elites and the myth of uncertainty amidst optimism remains rhetoric in Nepal but may prove a nightmare if not handled properly, and ultimately may bring the country to the crossroads, leading the nation to a threshold of failure state or a country in a phase of total turmoil or a status of being always in crisis owing to the lack of proper comprehension of elitism, economic, socio-cultural and regional idiosyncrasy.

\section{References}

Cosers, Lewis A (1964). The Functions of Social Conflict. The Free Press, New York.

Cosers, Lewis A (1976). Masters of Sociological Thoughts. Second Edition, Harcow Brace Jovanovich, Inc

Dahal, Dilli Ram (2000). “Nepal's democratic system has failed to cross the barriers of caste, family and kinship" in the Telegraph Weekly, Kathmandu, February 23, 2000.

Engles, Fredrick (1967). The Origins of the family, private property and the state. Foreign Language press, Peking

Harris, Marvin (1968). The Rise of Anthropological Theories, The Crowell Publication.

Layton, Robert (1993). An Introduction to Theory in Anthropology, Cambridge University Press.

Marx, Karl and Engles, Fredrick (1977). Manifesto of the Communist Party, Progress Publishers, Moscow

Mishra, Chaitanya (2007). Essays on Sociology of Nepal, FinePrint Inc, Kathmandu 